\title{
Problems of Personality Socialization: Changing the Value Priorities of Modern Youth
}

\author{
Svetlana Akutina ${ }^{1}$, Irina Begantsova ${ }^{1}$, Natalia Guseva ${ }^{1},{ }^{*}$ Tamara Shchelina ${ }^{1}$ \\ ${ }^{1}$ National Research Lobachevsky State University of Nizhny Novgorod, Russia \\ *Email:soleilfun@mail.ru
}

\begin{abstract}
The article deals with the problem of changing the value priorities of young men in the conditions of modern social reality. The concept of value orientations of personality is considered as a complex system and process that absorbs and reflects almost all contradictions and changes in the holistic picture of the worlds, which in their essence are the source of personality development. These contradictions arise between socialization and individualisation of the personality: on the one hand, people will inevitably socialise, learning the norms of society; on the other - strive to preserve the individuality of their personality; common values and the freedom they give the human norm and liberty - the two poles, two fightings began; the traditional value orientations and the update that is happening in the mind of the individual. The functions that perform value orientations are revealed: human-making, epistemological, regulatory (normative), axiological function. The authors studied the attitude to value and life-meaning orientations of young men at the unconscious and conscious level; it was revealed that modern young men actively prioritise the categories of beauty and pleasure in their lives and do not consider it essential to show their active life position at this age stage. This leads to the conclusion about the feminisation of modern young men in developing a civilizational society.
\end{abstract}

Keywords: Socialization, Personality, Value orientations and priorities, Life meaning orientations, Young men, Conscious, Unconscious, Youth.

\section{INTRODUCTION}

The problem of socialization of modern youth in the 21 st century has acquired an international character and continues to be actualised in the life of the contemporary world community. The increasing importance of successful socialization of the younger generation and, on this basis, the formation of value orientations is expressed in a sharp increase in international events aimed at attracting the attention of the world community to this burning topic and in attempts to find conditions conducive to awareness of the problem under consideration. Exploring and describing these phenomena, we realise that there are no ready-made models for the formation of value orientations of young people; in the context of our research, young men and their actualisation may occur outside of classical scientific theoretical concepts.
The socialization process in modern society is associated with holistic development processes occurring with a person at the level of a biological species - both teachers and psychologists note this. Thus, L. Rudkevich notes that at the present stage, there are several directions of human evolutionary transformations: asthenisation; deceleration or retardation of development, an increase in the proportion of persons with a dominant right hemisphere and ambidextrous in the population; juvenilisation; gracilisation; androgyny or gynandromorphy, etc. - all these morphological changes are accompanied by a whole cohort of psychological signs [1].

The value orientations of a person are formed in the general context of their socialization within a particular society, considering the general trends of human development as a representative of a certain temporal and socio-economic formation. 
Personal value orientations are a complex system and process that absorbs and reflects the contradictions of the whole world. Contradictions constitute the essential characteristic of values and are the source of their development [2]. These contradictions arise between socialization and individualisation of personality: on the one hand, a person inevitably socialises, assimilating the norms of society, on the other - strives to preserve the individuality of his personality; normativity of values and the freedom that they provide to a person: norm and freedom are two poles, two struggling principles; traditionality of value orientations and the renewal that occurs in the consciousness of the individual.

Value orientations have their laws of functioning.

Let's highlight the main ones: value orientations have an all-pervading ability to cover all aspects of human life and are integrative, combining various cultural forms into a single system of spiritual life. The crisis of values is always a sign of rethinking the development of society. Russian society is now interested in developing new value orientations of young people of cultural values that would unite the nation.

Value orientations are a multifunctional system that performs the following functions:

- human-making, including the translation of social experience, i.e. the function of historical continuity,

- cognitive or epistemological function concentrates in itself the best social experience of many generations of people, immanently acquires the ability to accumulate the most affluent knowledge about values and their development, acquisition,

- regulatory or normative function: definition and regulation of various aspects, types of public and personal activities of people,

- a proper value or axiological function, which is understood by us as a set of ethical values and norms, attitudes towards others and others, behaviour and lifestyle, in which it finds expression: respect for life, human personality, its dignity and rights, understanding and acceptance of differences between people in beliefs and beliefs, mutual understanding, as between peoples.

\section{METHODOLOGY}

The methodological basis of our research is the axiological (value) approach (B.M. Bim-Bad, B.S. Brushlinsky, B.I. Dodonov, A.G. Zdravomyslov [3], M.S. Kagan [3], N.D. Nikandrov, V.A. Slastenin, M.N. Fischer, P.G. Shchedrovitsky et al.), and the ideas of the system (I.V. Blauberg, V.N. Sadovsky, E.G. Yudin, A.D. Hall, R.I. Feijin, L. Bertalanfi, et al.), activity (M.Ya. Basov, S.L. Rubinstein, A.N. Leontiev, M.G. Yaroshevsky, et al.), cultural (A.I. Arnoldov, Yu.I. Efimov, I.I.Gromov, V.A. Malakhov, V.P. Tugarinov [4], N.Z.Chavchavadze, et al.), personal (K.A. Abulkhanova, J.A. Bolotova [5], I.S. Kon, A.V. Mudrik, K. Rogers, A. Maslow, R. May, V. Frankl et al.), sociological approaches (A.Yu. Gayfullin [6], G.D. Zimulina [7]).

Values are the highest principles, ideals that determine people's behaviour and ensure their mutual

Table 1. Testing the hypothesis of the normality of empirical data for young men

\begin{tabular}{|l|c|c|c|c|}
\hline \multirow{2}{*}{ Variable } & \multicolumn{4}{|c|}{ All Groups Tests of Normality } \\
\cline { 2 - 5 } & & $\max \mathrm{D}$ & $\begin{array}{c}\mathrm{K}-\mathrm{S} \\
\mathrm{p}\end{array}$ & $\begin{array}{c}\text { Lilliefors } \\
\mathrm{p}\end{array}$ \\
\hline AL CC & 60 & 0.115011 & $\mathrm{p}>.20$ & $\mathrm{p}<, 05$ \\
\hline AL UC & 60 & 0.131114 & $\mathrm{p}<, 20$ & $\mathrm{p}<, 01$ \\
\hline MAL CC & 60 & 0.141947 & $\mathrm{p}<, 15$ & $\mathrm{p}<, 01$ \\
\hline MAL UC & 60 & 0.197739 & $\mathrm{p}<, 01$ & $\mathrm{p}<, 01$ \\
\hline BEAUTY CC & 60 & 0.319845 & $\mathrm{p}<, 01$ & $\mathrm{p}<, 01$ \\
\hline BEAUTY UC & 60 & 0.166108 & $\mathrm{p}<, 05$ & $\mathrm{p}<, 01$ \\
\hline PLEASURE CC & 60 & 0.344676 & $\mathrm{p}<, 01$ & $\mathrm{p}<, 01$ \\
\hline PLEASURE UC & 60 & 0.286670 & $\mathrm{p}<, 01$ & $\mathrm{p}<, 01$ \\
\hline LW CC & 60 & 0.118170 & $\mathrm{p}>.20$ & $\mathrm{p}<, 05$ \\
\hline LW UC & 60 & 0.183211 & $\mathrm{p}<, 05$ & $\mathrm{p}<, 01$ \\
\hline
\end{tabular}


understanding and coordinated activity in society. The issues of the formation of value orientations of youth (personality), the search for semantic constructs, the formation of a worldview, successful socialization in society are widely discussed in modern psychological and pedagogical science (I.V. Abakumova, S.P. Akutina [2], A.G. Asmolov, I.S. Begantsova, N.V. Guseva [8], I.V. Dubrovina, A.V. Mudrik, V.S. Mukhina, V.I. Slobodchikov, T.T. Shchelina et al.) $[9,10,11]$. A broad discussion of the formation of value orientations and priorities of youth is explored in the works of L.P. Razbegaeva [12], O.A. Safonova [13], V.I. Slobodchikov [14] and other scientists [15].

The analysis of scientific literature allowed us to talk about a meaningful rethinking of the concept of "value orientations and priorities of modern young men", important parameters of which are such categories as life wisdom, pleasure, active life, material attitude to life, beauty, which, as it turned out in the course of our research, are quite significant for modern young men.

Research methods: theoretical (analysis of philosophical, social, psychological and pedagogical literature, dissertations on the research problem, scientific materials and publications; systematisation, classification, comparative analysis); empirical (observation, ascertaining experiment); methods of mathematical statistics and graphical representation of results.

Mathematical processing of the results of the empirical study was carried out using correlation, cluster and variance analysis using the statistical program SPSS13. The analysis of variance made it possible to assess the influence of gender role socialization factors and the form of reflection of reality on differences in values and life orientations (LO) in men in adolescence.

\section{RESEARCH RESULTS}

The study participants were university students aged 18 to 24 years, a totally of 60 people. The study used: $M$. Rokich's test [16] "Value orientations", MAM methodology (Metaphorical associative maps). Out of all terminal values and life-meaning orientations, according to the method of M. Rokich, we analysed the data obtained for independent variables of gender-role socialization, five motivationally different types of values were selected: pleasure (PLEASURE), active life (AL), beauty (BEAUTY), life wisdom (LW), material attitude to life (MAL). A further mathematical analysis was carried out according to the empirically obtained data.

For this study, the Lilliefors criterion was used, which is a variant of the well-known classical KolmogorovSmirnov criterion, specially modified to test the null hypothesis that the sample is distributed according to the normal law for the case when the parameters of the normal distribution (expectation and variance) are a priori unknown (Table 1).

The data obtained for independent variables: forms of reflection of reality, attitude to value and life-meaning

Table 2. Testing the hypothesis of the normality of empirical data in conscious and unconscious choices (CC and UC)

\begin{tabular}{|l|c|c|c|c|}
\hline \multirow{2}{*}{ Variable } & \multicolumn{3}{|c|}{ All Groups Tests of Normality } & L-S \\
\cline { 2 - 5 } & N & max D & $p$ & $p$ \\
\hline AL CC & 60 & 0.115011 & $p>.20$ & $p<.05$ \\
\hline AL UC & 60 & 0.131114 & $p<.20$ & $p<.01$ \\
\hline MAL CC & 60 & 0.141947 & $p<.15$ & $p<.01$ \\
\hline MAL UC & 60 & 0.197739 & $p<.01$ & $p<.01$ \\
\hline BEAUTY CC & 60 & 0.319845 & $p<.01$ & $p<.01$ \\
\hline BEAUTY UC & 60 & 0.166108 & $p<.05$ & $p<.01$ \\
\hline LOVE CC & 60 & 0.344676 & $p<.01$ & $p<.01$ \\
\hline LOVE UC & 60 & 0.286670 & $p<.01$ & $p<.01$ \\
\hline LW CC & 60 & 0.118170 & $p>.20$ & $p<.05$ \\
\hline LW UC & 60 & 0.183211 & $p<.05$ & $p<.01$ \\
\hline
\end{tabular}


Table 3. Correlation dependence of empirical data of conscious and unconscious choice

\begin{tabular}{|l|c|c|c|c|c|}
\hline \multirow{2}{*}{ Variable } & \multicolumn{5}{|c|}{ Correlations Marked correlations are significant at $p<, 05000 \mathrm{~N}=60$} \\
\cline { 2 - 6 } & AL UC & MAL UC & BEAUTY UC & PLEASURE UC & LW UC \\
\hline AL CC & -0.14 & 0.22 & 0.20 & -0.10 & 0.17 \\
\hline MAL CC & 0.08 & -0.17 & 0.00 & 0.14 & -0.15 \\
\hline BEAUTY CC & 0.37 & 0.10 & -0.41 & -0.08 & -0.12 \\
\hline PLEASURE CC & -0.17 & -0.08 & 0.12 & -0.16 & -0.08 \\
\hline LW CC & -0.09 & 0.24 & 0.02 & -0.22 & -0.24 \\
\hline
\end{tabular}

orientations in young men at the unconscious and conscious level are presented below (Table 2).

The obtained results presented in the tables confirm that no hidden data distorts the study and that the data in the sample are distributed according to the normal law.

At the stage of analysing the differences in value and life orientations among young men, a modern trend has emerged: young men actively prioritise the category of beauty in their lives and do not consider it essential to show their active life position at this age. This leads to the conclusion about the feminisation of young men at present.

Significantly, the value types are included in the most significant group in the conscious and unconscious choice of all the values and life orientations studied in our work.

The following data were obtained when identifying the correlation between conscious choice and unconscious (Table 3 ).

The results obtained lead to the conclusion that the relationship between beauty and active activity in life and between life wisdom and material attitude to life are included in the dominant pair. So, unconsciously, young men strive to be attractive in their lives; besides, they direct their wisdom to obtain material values. The more excellent the conscious choice of the category "beauty", the younger people are active in their lives at the level of unconscious attitudes. From Table 3, we see that the maximum positive values fall on the relationship between AL UC and BEAUTY CC, LW CC and MAL $\mathrm{UC}$; this shows that the younger people strive for material well-being, the more they do their life wisdom actively manifests itself.

At this stage of the analysis and interpretation of the study results, we carried out regression calculations of the manifestation of value orientations. Multiple regression methods allowed us to obtain a regression result for dependent variables. For all samples, we found the $\beta$ coefficient of regression, representing the independent variable's strength and type of relationship to the dependent one. We constructed regression models that visually interpreted the study results using these data. Below we selectively present the research data.

For the category of terminal value BEAUTY, the following results were obtained (Table 4).

The regression analysis obtained the following results for the dependent variable LW CC (life wisdom with conscious choice), where LW UC is an independent variable (Table 5). A regression relationship was obtained $\left(R^{2}=0.059\right.$, at $\left.\mathrm{P}=0.044\right)$.

Table 4. The data of the regression analysis of the BEAUTY value

\begin{tabular}{|l|c|c|c|c|c|c|}
\hline \multirow{2}{*}{\multicolumn{1}{|c|}{ N=60 }} & \multicolumn{6}{|c|}{ Regression Summary for Dependent Variable: BEAUTY CC $R=, 41167700 \mathrm{R}=, 16947795$ Adjusted } \\
\cline { 2 - 7 } & $\beta$ & $\begin{array}{c}\text { Std.Err. } \\
\text { of Beta }\end{array}$ & $\mathrm{B}$ & $\begin{array}{c}\text { Std.Err. } \\
\text { of B }\end{array}$ & $\mathrm{t}(66)$ & p-level \\
\hline Intercept & & & 20.84170 & 1.733490 & 12.02297 & 0.000000 \\
\hline BEAUTY UC & $-0,411677$ & 0.112177 & -0.85439 & 0.232812 & -3.66989 & 0.000487 \\
\hline
\end{tabular}


Table 5. Data from the LW (life wisdom) value regression analysis

\begin{tabular}{|c|c|c|c|c|c|c|}
\hline \multirow{2}{*}{$N=60$} & \multicolumn{6}{|l|}{ Regression Summary for Dependent Variable: LW CC $R=.24451341 R^{2}=.05978681$ Adjusted $R=.04554115$} \\
\cline { 2 - 7 } & $\beta$ & $\begin{array}{c}\text { Std.Err. } \\
\text { of Beta }\end{array}$ & $B(1.66)=4.1968 p$ & p-level \\
\hline Intercept & & & 14.88935 & 2.144339 & 6.94356 & 0.000000 \\
\hline LW UC & -0.244513 & 0.119355 & -1.02296 & 0.499343 & -2.04862 & 0.044480 \\
\hline
\end{tabular}

Since the $\beta$-coefficient of regression for the variable LW CC $(\beta=-0.244)$ has a negative value, this allows us to conclude:

- the more responsible and conscious young men are about their actions in life on a conscious level, the less they think about their attitudes of real social behaviour. This indicates internal irresponsibility to the future; young people do not think about how they behave now and what consequences this may lead to in the future; this behaviour can be characterised by the phrase "live one day".

The analysis of variance confirmed the apparent regularity of all the values of young people with a conscious choice from values at an unconscious level.

We have calculated all the average values of the variables, and we can analyse the deviation of the variables from their average values (Table 6).

As we see the data in Table 6, apart from the value of PLEASURE, all empirical data on other values depend on AL (active life).

We agree with the point of view of scientists T.K. Rostovskaya and T.B. Kaliev point out that "the changes taking place in society, the development of technologies, innovations in the education system and other processes taking place in the modern world are most strongly reflected in the value field of young people. The study of the value orientations of young people is essential not only for determining the dominant values at present but also for predicting possible changes" [17, 18], including in an innovative educational environment [19].

\section{CONCLUSIONS}

Conclusions formed based on the analysis of variance of empirical data depending on the AL:

- the values of conscious choice include AL "active life", LW "life wisdom", MAL "material attitude to life", BEAUTY "beauty";

- in this age period, the attitude of young people at an unconscious level to an active life is not significant, which means that the need to make efforts among young people in adolescence to improve the material side of life does not arise;

- a pronounced need for beauty, the desire to look good is the main motivating value in adolescence, social

Table 6. The dependence of values in a conscious choice on AL

\begin{tabular}{|c|c|c|c|c|c|c|c|c|c|c|c|}
\hline \multirow{2}{*}{$\begin{array}{c}\text { Dependent } \\
\text { Variable }\end{array}$} & \multicolumn{11}{|c|}{ Test of SS Whole Model vs SS Residual } \\
\hline & $\begin{array}{c}\text { Multiple } \\
\text { R }\end{array}$ & $\begin{array}{c}\text { Multiple } \\
R^{2}\end{array}$ & $\left|\begin{array}{c}\text { Adjusted } \\
R^{2}\end{array}\right|$ & $\begin{array}{c}\text { SS } \\
\text { Mode }\end{array}$ & $\begin{array}{c}\text { df } \\
\text { Modt }\end{array}$ & $\begin{array}{c}\text { MS } \\
\text { Model }\end{array}$ & $\begin{array}{c}\text { SS } \\
\text { Residu }\end{array}$ & $\begin{array}{c}\text { df } \\
\text { Residual }\end{array}$ & $\begin{array}{c}\text { MS } \\
\text { Residua }\end{array}$ & $\mathrm{F}$ & $p$ \\
\hline AL CC & 0.56368 & 0.31774 & 0.225232 & 422.558 & 8 & 52.8198 & 907.324 & 59 & 15.3783 & 3.43468 & 0.002619 \\
\hline MAL CC & 0.67282 & 0.45269 & 0.378478 & 438.230 & 8 & 54.7787 & 529.829 & 59 & 8.98015 & 6.09998 & 0.000010 \\
\hline BEAUTY CC & 0.48184 & 0.23217 & 0.128061 & 296.540 & 8 & 37.0675 & 980.695 & 59 & 16.6219 & 2.23003 & 0.037613 \\
\hline $\begin{array}{l}\text { PLEASURE } \\
\text { CC }\end{array}$ & 0.30952 & 0.09580 & $\begin{array}{c}- \\
0.026798\end{array}$ & 159.921 & 8 & 19.9901 & 1509.314 & 59 & 25.5816 & 0.78142 & 0.620655 \\
\hline LW CC & 0.47442 & 0.22507 & 0.120001 & 333.005 & 8 & 41.6257 & 1146.524 & 59 & 19.4326 & 2.14205 & 0.045596 \\
\hline
\end{tabular}


attractiveness for young men directly depends on external attractiveness;

- there is a correlation between the severity of the feminine components of psychological gender and the significance of values.

The absence of differences in the comparative analysis of the choice of values at the conscious and unconscious level among young men, as well as the priority choice of feminine qualities by men (young men), such as "beauty" and "pleasure", the shift from priority positions of values such as "active life" and "life wisdom" demonstrates the progressive infantilism of men in the modern generation. Young men with a high level of femininity strive for entertainment, lack responsibilities and ignore generally accepted social gender-role priorities; as a result, the importance of family relations, individual self-realisation are levelled.

Thus, young men in modern reality are less interested in material well-being, the prospect of their development, the desire for productive results, pleasure is increasingly essential in their interests, the value of "beauty" and external attractiveness is increasing. They demonstrate high expression of feminine qualities, infantilism, immaturity of emotional-volitional, value spheres.

The further stage of our research will be the development of a strategy of psychological and pedagogical support for the development of value orientations of young men with developing potential in the modern socio-cultural situation - this is the provision of conditions for the manifestation of the student's subjective position in forms of activity that help to show individuality and abilities in modern culture (strategy to support self-expression, "the value of self-realisation"); the creation of conditions for the search of young men for ways to realise personal potential in the course of selfknowledge (strategy to support self-knowledge and selfunderstanding, ("the value of the Self as a person"); the creation of conditions for the acquisition of experience of social interaction, participation in socio-cultural useful activity (strategy of support of social background, "the value of other people"); establishment of dialogical interaction with significant adults in the course of joint solution of value-oriented problems (strategy of meaningful cognition, "the value of cognition").

\section{ACKNOWLEDGMENT}

The team of authors expresses gratitude to the administration of the Arzamas branch of the NNSU for providing the research base.

\section{REFERENCES}

[1] L.A. Rudkevich, Epochal human changes at the present stage and pedagogical innovations [Epohal'nye izmeneniya cheloveka na sovremennom etape i pedagogicheskie innovacii] // Bulletin of Practical psychology of education [Vestnik prakticheskoj psihologii obrazovaniya] 4(5) (2005) 28-38

[2] S.P. Akutina, The formation of the life-meaning concept of modern students in the process of professional education at the university / S.P. Akutina, T.V. Kalinina [Formirovanie smyslozhiznennoj koncepcii sovremennogo studenchestva $\mathrm{V}$ processe professional'nogo vospitaniya v vuze / S.P. Akutina, T.V. Kalinina] // Scientific Dialogue [Nauchnyj dialog] 3(51) (2016) 255-266.

[3] M.S. Kagan, Philosophical theory of value [Filosofskaya teoriya cennosti] / M.S. Kagan, St. Petersburg: LLP TC "Petropolis", 1997, 205 p.

[4] V.P. Tugarinov, On the values of life and culture [O cennostyah zhizni i kul'tury], L.: Publishing House of LSU, 1960, 156 p.

[5] Zh.A. Bolotova, Z.U. Kolokolnikova, Yu.V. Kostrikova, E.A. Radchenko, M.N. Rakhmanova, Pedagogical values in domestic and foreign pedagogy (on the example of Ya.A. Komensky, N.G. Chernyshevsky, K.D. Ushinsky views) [Pedagogicheskie cennosti v otechestvennoj i zarubezhnoj pedagogike (na primere vzglyadov YA.A. Komenskogo, N.G. CHernyshevskogo, K.D. Ushinskogo)] // International Journal of Applied and Fundamental Research [Mezhdunarodnyj zhurnal prikladnyh i fundamental'nyh issledovanij] 1-2 (2016) 254-256. URL: https://appliedresearch.ru/ru/article/view?id=8361 (accessed: 12/15/2021).

[6] A.Yu. Gayfullin, Value orientations of modern youth: a sociological analysis [Cennostnye orientacii sovremennoj molodezhi: sociologicheskij analiz] // AlmaMater (Bulletin of the Higher School) [AlmaMater (Vestnik vysshej shkoly)] 2 (2018) 30-33

[7] G.D. Zimulina, The problem of the formation of value orientations of modern student youth [Problema formirovaniya cennostnyh orientacij sovremennoj studencheskoj molodezhi] // Psychology, sociology and pedagogy [Psihologiya, sociologiya i pedagogika], No. 42015 [Electronic resource].

URL: https://psychology.snauka.ru/2015/04/4858 (accessed: 08.12.2021).

[8] N.V. Guseva, I.S. Begantsova, Social partnership as a resource of the process of professional training of university students // Theory and practice of psychological and social work in modern society: a 
collection of articles by participants of the VII International Scientific and Practical Conference on March 24-25, 2021 / scientific. Ed. by S.P. Akutin, T.T. Shchelina [Social'noe partnerstvo kak resurs processa professional'noj podgotovki studentov vuza // Teoriya i praktika psihologo-social'noj raboty $\mathrm{v}$ sovremennom obshchestve: sbornik statej uchastnikov VII Mezhdunarodnoj nauchnoprakticheskoj konferencii 24-25 marta 2021 g. / nauch. Red. S.P. Akutina, T.T. SHCHelina] Arzamas: Arzamas branch of NNSU [Arzamas: Arzamasskij filial NNGU], 2021, pp. 136-138.

[9] T. Shchelina, Psychological-Pedagogical Diagnostics of the Development of Individuals and Groups in the Education of Modern Students / Tamara Shchelina; Svetlana Akutina; Irina Begantsova; Lyudmila Ageeva; Svetlana Shchelina // Revista ESPACIOS 38(35) (2017) 33. URL: http://www.revistaespacios.com/a17v38n35/17383 533.html

[10] S. Akutina, Forming teachers` moral and ethical competences: the standpoint of hermeneutic pedagogy and psychology WoS / Svetlana P. Akutina, Irina S. Begantsova, Tamara T. Shchelina // IFTE 2019 5th International Forum on Teacher Education 29-31 May 2019 // The European Proceedings of Social and Behavioural Sciences EpSBS 1(1) (2020) 189-197 DOI: https://doi.org/10.15405/epsbs.2020.01.24,https://d oi.org/10.15405/epsbs(2357-1330).2020.1.1

[11] T.T. Shchelina, Spiritual and value orientation of social educators: monograph [Duhovnocennostnaya orientaciya social'nyh pedagogov: monografiya] / T.T. Shchelina, M.: MPSU, 2006, $385 \mathrm{p}$.

[12] L.P. Razbegaeva, Universal humanistic values as a methodological source of designing the content of humanitarian education [Universal'nye gumanisticheskie cennosti kak metodologicheskij istochnik proektirovaniya soderzhaniya gumanitarnogo obrazovaniya] / L.P. Razbegaeva // Theoretical and methodological problems of modern education: a collection of scientific works [Teoretiko-metodologicheskie problemy sovremennogo vospitaniya: sb. nauch. Trudov], Volgograd: Publishing house "Change", 2004, p. 203.

[13] O.A. Safonova, Portrait of a "cultured person" of the 21 st century as a value-target guideline for the life self-determination of children and youth / O.A. Safonova // Vital self-determination of children and youth in modern society: materials of interuniversities scientific and practical conference of teachers of universities, colleges, postgraduates and students, N. Novgorod, April 17, 2009 [Portret «kul'turnogo cheloveka» 21 veka kak cennostnocelevoj orientir zhiznennogo samoopredeleniya detej i molodezhi/ O.A. Safonova // ZHiznennoe samoopredelenie detej i molodezhi v sovremennom obshchestve: m-ly mezhvuz. nauch.-prakt. konf. prepodavatelej vuzov, kolledzhej, aspirantov i studentov, N. Novgorod, 17 aprelya 2009g] - N. Novgorod: NGPU, 2009, 286 p.

[14] V.I. Slobodchikov, Spiritual problems of man in the modern world [Duhovnye problemy cheloveka $\mathrm{v}$ sovremennom mire] / V.I. Slobodchikov // Pedagogy 9 (2008) 33-39.

[15] New values of education. Anthropological, activity and cultural approaches. Thesaurus [Novye cennosti obrazovaniya. Antropologicheskij, deyatel'nostnyj i kul'turologicheskij podhody, Tezaurus], M.: School of Self-determination 5(24) (2005) 119-120.

[16] The method of M. Rokich's "Value orientations" [Metodika M.Rokicha «Cennostnye orientacii»] [Electronic resource]. URL: http://dippsi.ru/psikhologicheskiye-testy/post/metodika-mrokicha-tsennostnyye-oriyentatsii (Accessed 15.12.2021)

[17] T. Rostovskaya, Value orientations of modern youth: features and trends): monograph [Cennostnye orientiry sovremennoj molodezhi: osobennosti i tendencii): monografiya] / T.K. Rostovskaya, T.B. Kaliev, Moscow: RUSAINS, 2019, 228 p.

[18] T.K. Rostovskaya, T.B. Kaliev, The world of values of the younger generation of Russians and Kazakhstanis [Mir cennostej molodogo pokoleniya rossiyan i kazahstancev]. Values and Meanings [Cennosti i smysly] 1(53) (2018) 78-90.

[19] I. Begantsova, The Question of Students' Preparedness for Studying in the Digital Educational Environment / Irina S. Begantsova. Svetlana P. Akutina, Irina S. Begantsova, Tamara T. Shchelina // VI International Forum on Teacher Education. ARPHA Proceedings 3: VI International Forum on Teacher Education, 2020, pp. 207-218. 